\title{
Thoracic spinal cord compression secondary to metastatic synovial sarcoma: case report
}

Compressão da medula espinhal torácica por metástase secundária de sarcoma sinovial: relato de caso

\section{Compresión de la medula espinal torácica por metástasis secundaria de sarcoma sinovial: relato de caso}

\author{
Paul M. Arnold' \\ Michael C. Park ${ }^{2}$ \\ Kathy Newell ${ }^{3}$ \\ John J. Kepes ${ }^{3}$ \\ J. Brantley Thrasher ${ }^{4}$
}

\begin{abstract}
Synovial sarcoma is an uncommon malignant soft tissue neoplasm, occurring primarily in adolescents and young adults. It is prevalent in the periarticular soft tissues near large joints of the extremities and rarely involves the trunk. Metastases are not uncommon and usually involve the lungs; metastasis to the thoracic spine is rare. We report the case of a 47-year-old man with a history of synovial sarcoma of the lower back, with subsequent metastases to the lung, penis, and perineum (all previously resected), presenting with a 3-month history of low back pain and lower extremity paresthesias. Magnetic resonance imaging (MRI) demonstrated multiple lesions involving multiple contiguous vertebral bodies, with the mass at T12 compressing the spinal cord. The patient underwent T11-T12 laminectomy, transpedicular decompression, tumor debulking, and posterior fixation and fusion. The patient died six months later due to disease progression. Although
\end{abstract}

\section{RESUMO}

O sarcoma sinovial é uma neoplasia rara dos tecidos moles que afeta adolescentes e adultos jovens. A sua maior prevalência é nas grandes articulações das extremidades e raramente acomete o tronco. As lesões metastáticas são raras e geralmente acometem os pulmões, e as metástases para a coluna torácica são raras. Relata-se o caso de um paciente de 47 anos de idade com 3 meses de história de dor lombar e que apresentava metástase de sarcoma sinovial na coluna lombar. A ressonância magnética demonstrava lesões contíguas do corpo vertebral e compressão do canal vertebral ao nível de T12. O paciente foi submetido à laminectomia de T11T12, descompressão transpedicular, remoção tecido tumoral e artrodese e fixação posterior. O paciente foi a óbito após seis meses devido à progressão da doença. Embora a descompressão e estabilização cirúrgica do canal vertebral não sejam curativas,

\section{RESUMEN}

El sarcoma sinovial es una neoplasia rara de los tejidos blandos que afecta adolescentes y adultos jóvenes. Su mayor prevalencia es en las grandes articulaciones de las extremidades y raramente ataca el tronco. Las lesiones metastásicas son raras y generalmente atacan los pulmones, siendo que las metástasis de columna torácica son raras. Será relatado el cuadro clínico de un paciente de 47 años de edad con tres meses de historia de dolor lumbar y presentando metástasis de sarcoma sinovial en la columna lumbar. La resonancia magnética demostraba lesiones contiguas del cuerpo vertebral y compresión del canal vertebral al nivel de T12. El paciente fue sometido a la laminectomía de T11-T12, descompresión transpedicular, remoción de tejido tumoral y artrodesis con fijación posterior. El paciente fue a óbito después de seis meses debido a la progresión de la enfermedad. Aunque la descompresión y estabilización

\footnotetext{
University of Kansas Medical Center - Kansas City KS, USA.

'MD; Department of Neurosurgery of University of Kansas Medical Center - Kansas City KS, USA.

${ }^{2} \mathrm{MD}$; PhD; Department of Clinical Neurosciences Program in Neurosurgery Brown Medical School - Providence RI, USA.

${ }^{3} \mathrm{MD}$; Department of Pathology and Laboratory Medicine of University of Kansas Medical School - Kansas City KS, USA.

${ }^{4} \mathrm{MD}$; Department of Urology of University of Kansas Medical Center - Kansas City KS, USA.

The authors declare that there are no conflicts of interest
} 
not curative, decompression and stabilization of the spine are often necessary in patients who present spinal cord compression. esses procedimentos podem ser necessários em pacientes que apresentam compressão da medula espinhal. quirúrgica del canal vertebral no sea curativa, ese procedimiento puede ser necesario en los pacientes que presentan compresión de la médula espinal.
KEYWORDS: Sarcoma, synovial; Neoplasm metastasis; Spinal cord compression; Spinal neoplasms/secondary; Thoracic vertebrae/pathology; Laminectomy; Spinal fusion; Case reports
DESCRITORES: Sarcoma sinovial; Metástase neoplásica; Compressão da medula espinal; Neoplasias da coluna vertebral/secundário; Vértebras torácicas/patologia; Laminectomia; Fusão vertebral; Relatos de caso
DESCRIPTORES: Sarcoma sinovial/secundario; Metástasis de la neoplasia; Compresión de la médula espinal; Neoplasias de la columna vertebral/secundario; Vértebras torácicas/patología; Laminectomía; Fusión vertebral; Informes de casos

\section{INTRODUCTION}

Synovial sarcoma is a rare malignant neoplasm of the soft tissue that usually arises near a large joint in the extremities (especially the knee), most often in adolescents or young adults ${ }^{1}$. Rarely, it is also found in the head and neck region, the chest, the abdominal wall, and the lower back. Metastasis of synovial sarcoma is not uncommon, and affects the lung more frequently. We present a case of synovial sarcoma first appearing in the lower back, with subsequent separate metastases to the lung, penis, prostate and surrounding fibroadipose tissue, then finally to the thoracic spine, with the mass at T12 compressing the spinal cord.

\section{CASE REPORT}

A 47-year-old man presented with a three-month history of low back pain radiating to the right side of the midline. He had a history of synovial sarcoma of the right lower back, originally diagnosed in 1992 at 38 years old, and staged as III a,b (T1, N0, M0, GIII) when initially resected. This sarcoma was followed by external beam radiation treatment for seven weeks. The patient presented, in 1997, metastasis in the left upper lobe of the lung and subsequently underwent thoracotomy with lobectomy, followed by a second surgery for recurrence four months later.

In 1998, the patient was found to have a penile lesion, which was biopsied and found to be consistent with synovial sarcoma. He subsequently received a 70 Gy radiation treatment. In 2000, he underwent total penectomy and perineal urethrostomy for recurrent synovial sarcoma, with an uneventful postoperative course.

The patient began complaining about low back pain seven months later, which was initially controlled by antiinflammatory medication and morphine. The patient also complained about lower extremity paresthesias, but did not complain about any bowel or bladder incontinence. Neurological examination was normal. Magnetic resonance imaging of the thoracolumbar spine demonstrated lesions in five contiguous segments with circumferential compression at T11-T12, with the mass at T12 compressing the spinal cord. (Figure 1)
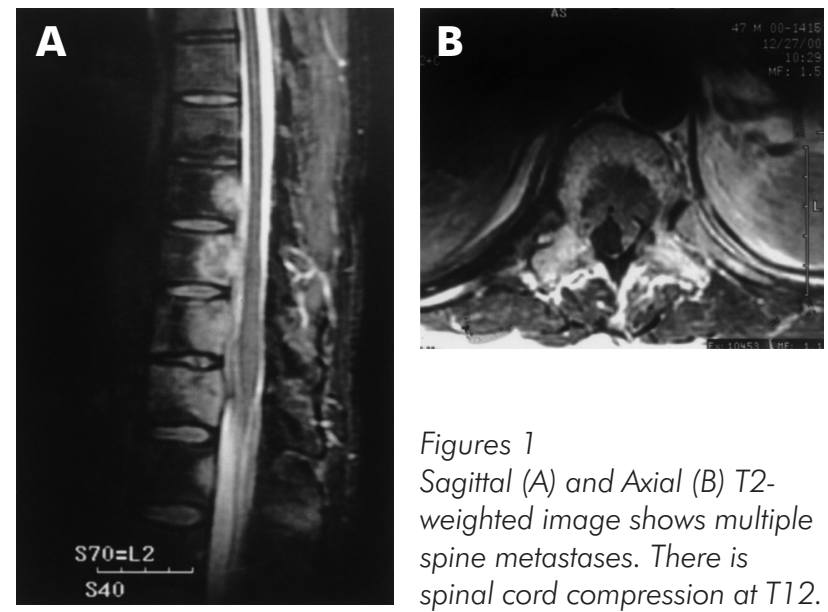

Figures 1

Sagittal (A) and Axial (B) T2-

weighted image shows multiple spine metastases. There is spinal cord compression at T12.

The patient underwent T11-T12 laminectomy, transpedicular decompression, tumor debulking, T7-L3 transverse process fusion with iliac crest bone graft, and pedicle screw fixation (Figure 2). The tumor, which appeared to

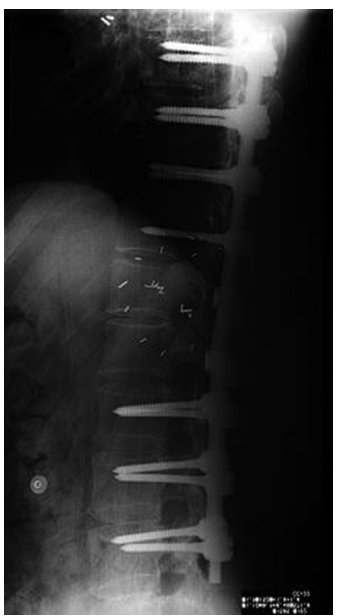

Figures 2

Lateral (A) and A-P (B)

$X$-rays demonstrate T1 1-T12 laminectomy, transpedicular decompression, tumor debulking, T7-L3 transverse process fusion with iliac crest bone graft, and pedicle screw fixation. 
be encapsulated, could be seen ventral and lateral to the spinal cord. Much of the tumor had a liquid consistency and was easily suctioned out.

Pathological evaluation revealed synovial sarcoma consistent with previously recovered tissue (Figure 3), representing a highly cellular small cell malignant neoplasm with tumor cells having scant cytoplasm, occasionally demonstrating eccentric small hyperchromatic nuclei, seemingly pushed aside by eosinophilic cytoplasm lending some of the tumor cells a somewhat "rhabdoid" shape. The tumor cells also could be seen as compressing capillary blood vessels to a narrow slit; the endothelial lining cells of those vessels, however, appeared to be normal, though slightly elongated under the pressure. The close apposition

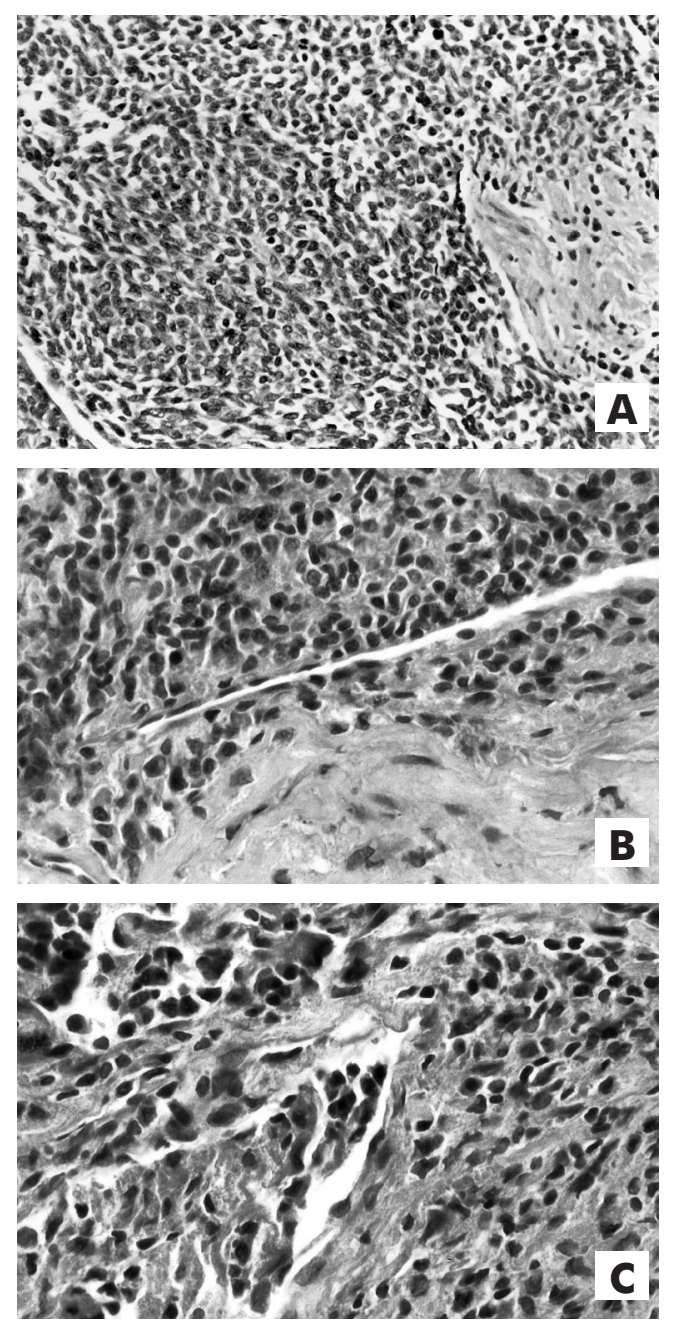

Figure 3

(A) Synovial cell sarcoma. Microscopically, the tumor is composed of densely packed small spindle-shaped cells with hyperchromatic nuclei and scant cytoplasm. (hematoxylin and eosin, original magnification, 200X); (B e C) metastatic synovial cell sarcoma to spinal epidural and vertebral tissue. Part of the tumor is intravascular and morphologically identical to the previously resected tumors (hematoxylin and eosin; original magnification, 400X). of tumor cells to the small vessel walls extending to the immediate subependymal layer of the vessels is highly reminiscent of the pattern seen in hemangiopericytomas cases. This subgroup of synovial sarcomas having (at least focally) a pattern very similar to that of hemangiopericytomas, has been previously reported ${ }^{1}$. In addition, in many areas of the excised tumor, numerous intraluminal tumor cells could also be observed in the blood vessels (mostly capillaries and venules).

The patient's postoperative period went well, as he was discharged to home on the fourth postoperative day. Subsequent postoperative X-rays showed the hardware in place. He remained neurologically normal. However, the patient died six months after surgery due to progression of disease.

\section{DISCUSSION}

Metastatic disease involving the spinal column is a significant source of morbidity in patients with cancer ${ }^{2-8}$, causing compression of the spinal cord, cauda equina, and nerve roots ${ }^{4,6}$. Epidural spinal cord compression (ESCC) develops in $5 \%$ of all cancer patients, and most often occurs in the thoracic spine $(60 \%)$, followed by the lumbosacral spine $(30 \%)$ and cervical spine $(10 \%)^{9}$. Vertebral body metastases may cause local, radicular, or axial pain, in addition to a variety of neurologic deficits from mild radicular weakness to paraparesis 7 . In autopsy studies of cancer patients, metastatic deposits in the spine have been observed in up to $90 \%$ of the patients, and symptomatic disease will develop in approximately $30 \%$ of patients $^{2,10}$. The thoracic region of the spine is involved in approximately $70 \%$ of cases $^{2}$.

Synovial sarcomas are uncommon malignant soft tissue neoplasms, representing less than $1 \%$ of all cancers ${ }^{11,12}$ and accounting for an estimated 5 to $10 \%$ of all soft tissue sarcomas ${ }^{11-15}$. It is the fourth most common soft-tissue sarcoma in adults ${ }^{16}$ after malignant fibrous histiocytoma, liposarcoma, and rhabdomyosarcoma ${ }^{15}$.

Synovial sarcoma occurs primarily in adolescents and young adults between 15 and 40 years of age, affecting males more frequently than females ${ }^{11,12,15,17,18}$. It usually arises in the periarticular regions near large joints, with 75 to $90 \%$ of cases involving the extremities ${ }^{11,15}$, especially the lower extremity ${ }^{15}$. A wide variety of other anatomic primary sites have been reported, including heart, lungs, small intestine and peripheral nerves ${ }^{13,19-21}$. Only 5 to $15 \%$ of cases involve the head and neck region, the trunk (including the abdominal wall and the retroperitoneum) ${ }^{11}$ and the lower back ${ }^{22,23}$.

More than $95 \%$ of synovial sarcomas have a characteristic chromosomal translocation with a resultant fusion gene of SYT and one of 3 SSX genes ${ }^{1,13,14}$. Despite the understanding of the molecular biology underlying synovial sarcoma, its cells of origin remain unkno$\mathrm{wn}^{13,24-26}$. Synovial sarcoma is histogenetically unrelated to synovium ${ }^{12,18,27}$; the term "synovial" sarcoma is 
due to the synovial differentiation of the tumor which is believed to originate from multipotential mesenchymal cells ${ }^{17}$; thus, synovial sarcoma is a mesenchymal tumor of unknown histogenesis that does not arise in synovial membranes ${ }^{13}$.

Synovial sarcoma is characterized by epithelial-like and spindle cell components arranged in a biphasic or monophasic pattern; there is also a poorly differentiated (PD) form $^{14}$. Synovial sarcomas are microscopically divided into four histological subtypes: biphasic (the most predominant type); monophasic fibrous; monophasic epithelial; and poorly differentiated; the biphasic type contains a glandular component in addition to the monophasic spindle cells ${ }^{12,13,15,27}$.

Synovial sarcoma remains one of the most aggressive soft-tissue sarcomas, despite improvements in staging, surgical technique, and adjuvant therapies ${ }^{15}$. According to Baptista et al. ${ }^{15}$, most pathologists consider synovial sarcoma as a high-grade soft-tissue sarcoma, though they consider the biologic behavior, in some cases, to be more benign than others ${ }^{15}$. According to de Silva, development of local recurrence carries an increased risk for development of metastases and tumor-related death ${ }^{16}$. Metastatic recurrence is determined by three independent factors: tumor grade, tumor size $(>5 \mathrm{~cm})$, and histopathology ${ }^{28}$. Disease-free survival (freedom from local, lymph node, and metastatic recurrence) correlates with tumor grade, tumor size, microscopic resection margin, presentation, tumor site, patient age, and histologic subtype ${ }^{28}$. Disease-specific survival (reflecting the effects of disease recurrence and the outcome of salvage therapy) correlates with tumor grade, tumor size, tumor site, histopathology, patient age, and resection margins. ${ }^{28}$ Tumor grade, size, and histopathology exerted their effect largely through their influence on metastatic recurrence, while tumor site, patient age, and resection margins exerted their effect through predisposing to local recurrence ${ }^{28}$.

Although metastases of synovial sarcomas are not uncommon, with an involvement of more than half of all cases, the organ that is most frequently affected by synovial sarcoma metastases is the lung ${ }^{11,15,17,18,29}$, followed by the liver and skeletal system. Synovial sarcoma with metastasis to the thoracic spine is unusually rare. In a series of 59 patients, Bilsky noted three spindle cell sarcoma metastases to the spine, but did not specify a level ${ }^{30}$. Merimsky et al., in a series of 19 cases, reported one patient with a T7-8 synovial sarcoma metastasis. This patient was treated with radiation therapy. This patient's pain resolved but not her motor and sensory disturbances ${ }^{31}$. Suh et al. reported an epidural synovial sarcoma metastasis at L4-5. This patient underwent an L4-5 hemilaminectomy with tumor resection; the tumor was noted to be extending through the right L4 foramen and into the soft tissues. The patient had symptomatic improvement at the fifth month of follow-up ${ }^{22}$. Otsuka et al. reported an L5 metastasis that was also surgically resected $^{32}$. Signorini et al. resected a T2 synovial sarcoma following paraplegia. Following a subtotal resection, the patient died three months later ${ }^{33}$. Sakellaridis resected a hemangiopericytoma-like synovial sarcoma from the lumbar spine of a 36-year-old woman; she died eighteen months later due to multiple recurrences ${ }^{34}$.

There were also rare reports of intradural synovial sarcoma metastasis. Greene et al. reported an 11-year-old girl who had multiple intradural extramedullary metastases, most notably at L2-4. This was the initial manifestation of her disease. The patient had this tumor resected but died 14 months after diagnosis ${ }^{13}$. Scollato et al. reported the case of a 59-year-old man with intramedullary metastasis at $\mathrm{C} 3-5^{35}$.

Clinical management of spine tumors, including metastatic disease, has undergone drastic evolution in the past few years. Treatment of spinal column metastases is seldom curative, thus the goal in most cases is palliation? ${ }^{7}$. Median survival after ESCC diagnosis is four to six months .

Advances in magnetic resonance imaging, sophisticated instrumentation for spinal stabilization, and an increased understanding of the biomechanics of the spine have led to increased treatment options for spine metastases. The advent of spinal instrumentation, as well as transpedicular or ventral decompression, has allowed favorable outcomes in treating and possibly reversing significant neurological deficit in comparison to previous treatment methods of radiation, decompressive laminectomy without stabilization, or combined radiation and laminectomy. Several authors reported rates of neurological improvement nearing $70 \% \%^{2,6,36-39}$, a significant improvement compared to traditional therapies, after the refinement of anterior spinal approaches and the introduction of more reliable segmental spinal stabilization systems for both anterior and posterior reconstructions ${ }^{2}$. These same authors also demonstrated that superior rates of pain relief could be achieved when anterior or posterior stabilization was combined with neural decompression to eliminate tumorrelated axial spine instability ${ }^{2}$. Patchell et al. has shown that surgery followed by radiation yields better neurologic outcomes than radiation alone ${ }^{40}$.

Synovial sarcoma is an uncommon malignant soft tissue tumor, which rarely metastasizes to the spine. We report an unusual patient who presented multiple thoracic spine lesions, and was successfully treated with decompression, fusion, and fixation.

\section{ACKNOWLEDGEMENTS}

The authors thank Karen K. Anderson for her editorial assistance in the preparation of this manuscript. 


\section{REFERENCES}

1. Weiss SW, Goldblum JR. Synovial sarcoma. In: Weiss SW, Goldblum JR, editors. Enzinger and Weiss's soft tissue tumors. 4th ed. St. Louis: Mosby; 2001. p. 1483-509.

2. Holman PJ, Suki D, McCutcheon I, Wolinsky JP, Rhines LD, Gokaslan ZL. Surgical management of metastatic disease of the lumbar spine: experience with 139 patients. J Neurosurg Spine. 2005;2(5):550-63.

3. Harrington KD. Anterior cord decompression and spinal stabilization for patients with metastatic lesions of the spine. J Neurosurg. 1984;61(1):107-17.

4. Harrington KD. Metastatic disease of the spine. J Bone Joint Surg Am. 1986;68(7):1110-5.

5. Harrington KD. Anterior decompression and stabilization of the spine as a treatment for vertebral collapse and spinal cord compression from metastatic malignancy. Clin Orthop Relat Res. 1988;(233):177-97.

6. Sundaresan SN, Krol G, Digiacinto GV, Hughes JEO. Metastatic tumors of the spine. In: Sundaresan SN, Schmidek HH, Schiller AL, Rosenthal DI, editors. Tumors of the spine: diagnosis and clinical management. Philadelphia: W.B. Saunders; 1990. p. 279-304.

7. Ratliff JK, Cooper PR. Metastatic spine tumors. South Med J. 2004;97(3):246-53.

8. Wong DA, Fornasier VL, MacNab I. Spinal metastases: the obvious, the occult, and the impostors. Spine. 1990;15(1):1-4.

9. Management of spinal cord compression. J Support Oncol [Internet]. 2008;6(2):88-90. [cited 2008 Mar 3]. Available from: http:// www.oncologystat.com/journals/ew/ manual_journals/Management_of_ Spinal_Cord_Compression.html;jsessi onid=755ED05B37574ED9376B3276 51F6A1E888-90

10.Tatsui H, Onomura T, Morishita S, Oketa M, Inoue T. Survival rates of patients with metastatic spinal cancer after scintigraphic detection of abnormal radioactive accumulation. Spine. 1996;21(18):2143-8.

11.Enzinger FM, Weiss SW. Synovial sarcoma. In: Enzinger FM, Weiss SW. Soft tissue tumors. 3rd ed. St. Louis: Mosby-Year Book; 1995. p. 757-86.
12.Das Gupta TK, Chaudhuri PK. Tumors of the synovial tissue. In: Das Gupta TK, Chaudhuri PK, editors. Tumors of the soft tissues. 2nd ed. Stamford: Appleton and Lange; 1998. p. 397-406.

13. Greene S, Hawkins DS, Rutledge JC, Tsuchiya KD, Douglas J, Ellenbogen RG, et al. Pediatric intradural extramedullary synovial sarcoma: case report. Neurosurgery. 2006;59(6):E1339; discussion E1339.

14.Ferrari A, Gronchi A, Casanova M, Meazza C, Gandola L, Collini P, et al. Synovial sarcoma: a retrospective analysis of 271 patients of all ages treated at a single institution. Cancer. 2004;101(3):627-34.

15.Baptista AM, Camargo OP, Croci AT, Oliveira CR, Azevedo Neto RS, Giannotti MA, et al. Synovial sarcoma of the extremities: prognostic factor for 20 nonmetastatic cases and a new histologic grading system with prognostic significance. Clinics (Sao Paulo). 2006;61(5):381-6.

16.de Silva MV, McMahon AD, Reid R. Prognostic factors associated with local recurrence, metastases, and tumor-related death in patients with synovial sarcoma. Am J Clin Oncol. 2004;27(2):113-21.

17.Iwata T, Nishiyama N, Izumi N, Tsukioka T, Suehiro S. Metastatic monophasic synovial sarcoma of the pleura. Ann Thorac Cardiovasc Surg. 2007;13(4):258-61.

18.Kulander BG, Bolen JW. Pathology of soft-tissue sarcomas. In: Raaf JH, editor. Soft tissue sarcomas: diagnosis and treatment. St. Louis: Mosby; 1993. p. 43-68.

19.Bosma JJ, Kirollos RW, Broome J, Eldridge PR. Primary intradural classic chondrosarcoma: case report and literature review. Neurosurgery. 2001;48(2):420-3.

20.Okcu MF, Munsell M, Treuner J, Mattke A, Pappo A, Cain A, et al. Synovial sarcoma of childhood and adolescence: a multicenter, multivariate analysis of outcome. J Clin Oncol. 2003;21(8):1602-11.

21.Spillane AJ, A'Hern R, Judson IR, Fisher C, Thomas JM. Synovial sarcoma: a clinicopathologic, staging, and prognostic assessment. J Clin Oncol. 2000;18(22):3794-803.
22.Suh SI, Seol HY, Hong SJ, Kim JH, Kim JH, Lee JH, et al. Spinal epidural synovial sarcoma: a case of homogeneous enhancing large paravertebral mass on MR imaging. AJNR Am J Neuroradiol. 2005;26(9):2402-5.

23.Rangheard AS, Vanel D, Viala J, Schwaab G, Casiraghi O, Sigal R. Synovial sarcomas of the head and neck: CT and MR imaging findings of eight patients. AJNR Am J Neuroradiol. 2000;22(5):851-7.

24.Guillou L, Coindre J, Gallagher G, Terrier P, Gebhard S, de Saint Aubain Somerhausen N, et al. Detection of the synovial sarcoma translocation $\mathrm{t}(\mathrm{X} ; 18)$ (SYT;SSX) in paraffin-embedded tissues using reverse transcriptase-polymerase chain reaction: a reliable and powerful diagnostic tool for pathologists. A molecular analysis of 221 mesenchymal tumors fixed in different fixatives. Hum Pathol. 2001;32(1):105-12.

25.Kawai A, Woodruff J, Healey JH, Brennan MF, Antonescu Cr, Ladanyi M. SYT-SSX gene fusion as a determinant of morphology and prognosis in synovial sarcoma. N Engl J Med. 1998;338(3):15360. Comment in: N Engl J Med. 1998;338(3):192-4. N Engl J Med. 1998;338(23):1699.

26.Ladanyi M, Antonescu CR, Leung DH, Woodruff JM, Kawai A, Healey $\mathrm{JH}$, et al. Impact of SYT-SSX fusion type on the clinical behavior of synovial sarcoma: a multi-institutional retrospective study of 243 patients. Cancer Res. 2002;62(1):135-40.

27.Chung EB. Progress in malignant soft tissue tumours. In: Fletcher CDM, McKee PH, editors. Pathobiology of soft tissue tumors. Edinburgh: Churchill Livingstone; 1990. p. 295-318.

28.Zagars GK, Ballo MT, Pisters PW, Pollock RE, Patel SR, Benjamin RS, et al. Prognostic factors for patients with localized soft-tissue sarcoma treated with conservation surgery and radiation therapy: an analysis of 1225 patients. Cancer. 2003;97(10):2530-43.

29.Paulino AC. Synovial sarcoma prognostic factors and patterns of failure. Am J Clin Oncol. 2004;27(2):122-7. 
30.Bilsky MH, Boland PJ, Panageas KS, Woodruff JM, Brennan MF, Healey JH. Intralesional resection of primary and metastatic sarcoma involving the spine: outcome analysis of 59 patients. Neurosurgery. 2001;49(6):1277-86; discussion 1286-7.

31.Merimsky O, Kollender Y, Bokstein F, Issakov J, Flusser G, Inbar MJ, et al. Radiotherapy for spinal cord compression in patients with softtissue sarcoma. Int J Radiat Oncol Biol Phys. 2004;58(5):1468-73.

32. Otsuka N, Morita R, Yamamoto T, Muranaka A, Tomomitsu T, Yanagimoto S, et al. A case of synovial sarcoma with bone metastasis identified by bone marrow scintigraphy. Clin Nucl Med. 1985;10(4):260-3.

33. Signorini GC, Pinna G, Freschini A, Bontempini L, Dalle Ore G. Synovial sarcoma of the thoracic spine. A case report. Spine. 1986;11(6):629-31.

34. Sakellaridis N, Mahera H, Pomonis S. Hemangiopericytoma-like synovial sarcoma of the lumbar spine. Case report. J Neurosurg Spine. 2006;4(2):179-82.
35. Scollato A, Buccoliero AM, Di Rita A, Gallina P, Di Lorenzo N. Intramedullary spinal cord metastasis from synovial sarcoma. Case illustration. J Neurosurg Spine. 2008;8(4):400.

36.Bauer HC. Posterior decompression and stabilization for spinal metastases. Analysis of sixty-seven consecutive patients. J Bone Joint Surg Am. 1997;79(4):514-22. Comment in: J Bone Joint Surg Am. 1998;80(9):1396.

37.Gokaslan ZL, York JE, Walsh GL, McCutcheon IE, Lang FF, Putnam JB $\mathrm{Jr}$, et al. Transthoracic vertebrectomy for metastatic spinal tumors. J Neurosurg. 1998;89(4):599-609.

38.Siegal T, Siegal T. Surgical decompression of anterior and posterior malignant epidural tumors compressing the spinal cord: a prospective study. Neurosurgery. 1985;17(3):424-32.

39. Siegal T, Tiqva P, Siegal T. Vertebral body resection for epidural compression by malignant tumors. Results of forty-seven consecutive operative procedures. J Bone Joint Surg Am. 1985;67(3):375-82.
40.Patchell RA, Tibbs PA, Regine WF, Payne R, Saris S, Kryscio RJ, et al. Direct decompressive surgical resection in the treatment of spinal cord compression caused by metastatic cancer: a randomised trial. Lancet. 2005;366(9486):643-8. Comment in: ACP J Club. 2006;144(2):38. Lancet. 2005;366(9486):609-10. Lancet. 2006;367(9505):109; author reply 109-10. Lancet. 2006;367(9505):109; author reply 109-10.

\section{Correspondence:}

Paul M. Arnold

Spinal Cord Injury Center of the Department of Neurosurgery of University of Kansas Medical Center

3901 Rainbow Boulevard, MS 3021

Kansas City KS 66160

Tel.: (913) 588-7587

Fax: (913) 588-7596

E-mail: parnold@kumc.edu 